\title{
VAV1 Gene
}

National Cancer Institute

\section{Source}

National Cancer Institute. VAV1 Gene. NCI Thesaurus. Code C18365.

This gene plays a role in signal transduction. It is involved in the development and activation of both $B$ cells and $T$ cells. 